\title{
PELIICANS, CORMORANTS AND GREAT BLUE HERONS IN SASKATCHEWAN IN 1976
}

KEITH RONEY, Saskatchewan Museum of Natural History, Regina, Saskatchewan S4S 0B3

ABSTRACT. During the summer of 1976, a survey of colonial nesting species was conducted for the Museum of Natural History. Emphasis was placed on the White Pelican, Double-crested Cormorant and Great Blue Heron.

The survey indicated a slight reduction in the overall pelican population in Saskatchewan with significant changes within individual colonies. The cormorant seems to be enjoying more success than the pelican and appears to be slowly increasing in numbers.

The population status of the Great Blue Heron was not determined due to insufficient censusing.

Further surveys are needed to constantly monitor colonial bird status within the province.

Additional provincial legislation for greater protection of pelican and cormorant colonies is urgently required.

INTRODUCTION. "But the pelicans stood silent and dignified until they decided to leave and then, as if by one common impulse, they all rose at once with a great flapping of long blacktipped wings; they seemed heavy, awkward, and ungainly at first, but they soon gained headway and showed their marvelous mastery of the air, as they swung into line forming one large $\checkmark$-shaped flock; they circled around the island two or three times, with slow and dignified wing beats in military precision, or all scaled in unison like well-drilled soldiers; and finally, when satisfied that they must leave and when fully arranged in proper marching order, they all followed their leader and departed northward over the lake; the last we saw of them they were flying in a long straight line, just above the horizon, their black-tipped wings keeping perfect step and their snowy plumage showing clearly cut against the cold gray sky even when miles away. It was a fascinating spectacle to stand and gaze at that departing flock of magnificant birds and to dream of nature's wonders, the marvels of creation, which only those may see who seek the solitudes of remote wilderness lakes."

This early descriptive account of White Pelicans taking wing can still be enjoyed in all its grandeur today. But how long will this enjoyment last? The remote wilderness lakes where many of the pelicans have nested for years are quickly becoming polluted by human activity. This holds true for many of the other colonial nesting species as well. Decreasing the remoteness of the breeding areas can have a detrimental effect on the overall production. Human interference and disturbance has been the main factor in the decline or disappearance of some former breeding colonies.

Colonial nesters such as White Pelicans, Double-crested Cormorants, and Great Blue Herons are nervous birds and quite unprotective of their eggs or young. As a result, they are extremely prone to nest desertion and, consequently, breeding success may be reduced considerably or there may be no productivity whatsoever.

Saskatchewan accommodates signifiant percentage of some of the colonial species nesting in Canada. Foi example, in 1968, approximately 47 pei cent of all the White Pelican nests ir Canada were in Saskatchewan. ${ }^{5}$ It is imperative then that close vigilance be 


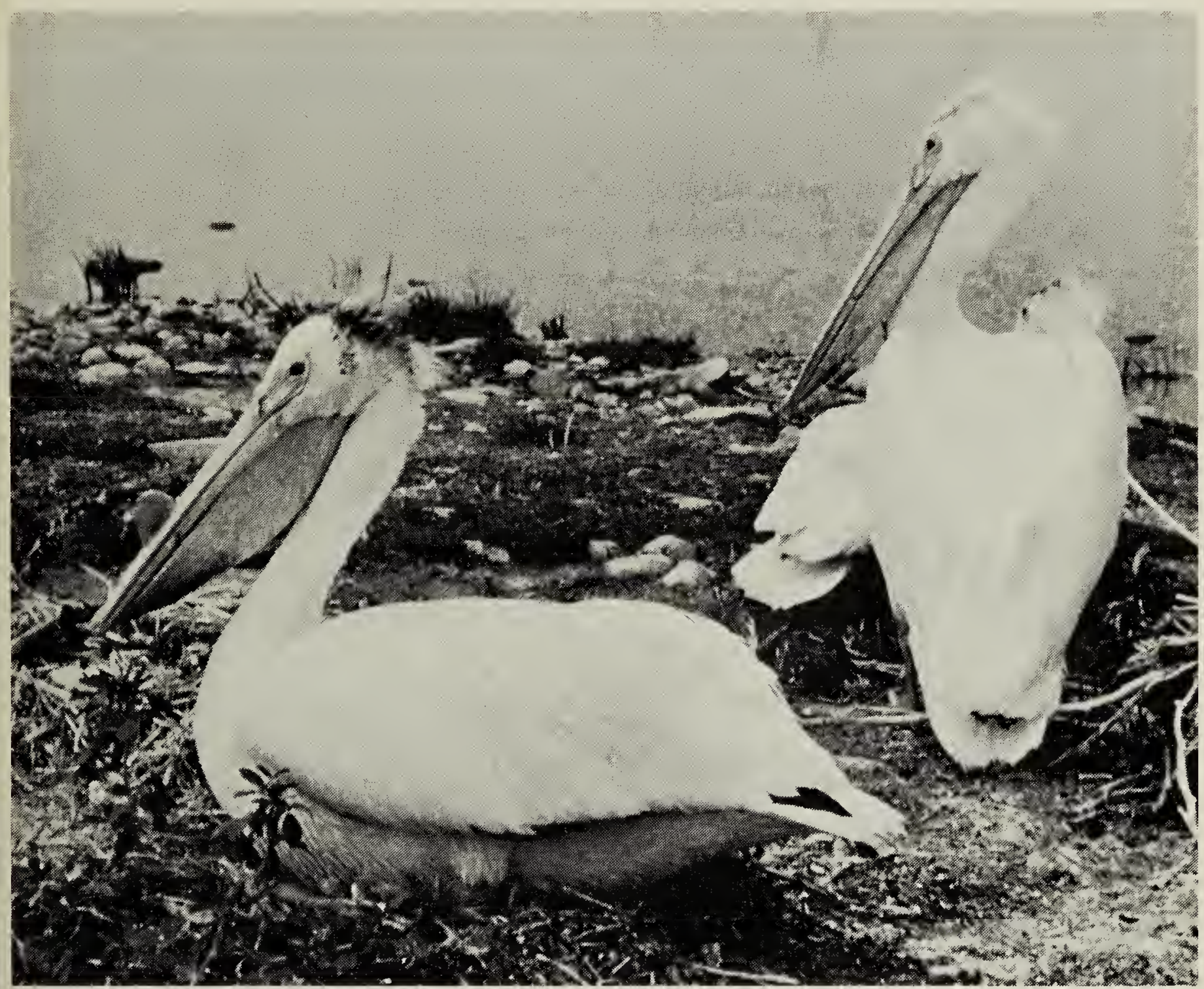

White Pelicans

Fred W. Lahrman

kept on the status of colonical nesters, in particular those species that are extremely susceptible to nest desertion.

The White Pelican's status has gone unchecked since 1971, Double-crested Cormorants since 1968, and Great Blue Herons since 1970. ${ }^{26} 7$ Acknowledging the delicate situation and nature of the birds, I undertook to survey as many existing colonies as possible. Extreme care was exercised in counting the birds so as to minimize disturbance.

Other colonial nesters, such as gulls and terns, were noted whenever possible. However, since these species can tolerate a high level of disturbance and since they actively defend their eggs and young, their population levels do not appear to be in jeopardy at this time. Consequently, I did not concern myself with extensively surveying them. However, since no surveys have been made to determine the size and distribution of gull and tern populations in Saskatchewan, a study would be most beneficial in the near future.

METHODS. I conducted my field work from May 13 to July 8, 1976. Methods for surveying varied from shank's mare, canoe and inflatable boat to airplane.

The Great Blue Heron colonies in the southern part of the province were checked first. The heron, pelican and cormorant colonies to the north were checked later, allowing ample time for the birds to establish themselves.

The majority of the heron colonies were examined by driving to the general vicinity, walking to the colony and counting the number of nests. Nests containing adult birds were considered active and those nests containing no birds or in a dilapidated condition were considered non-active. 


\begin{tabular}{|c|c|c|c|c|c|c|}
\hline LOC & ation & Date & Adults & Nests & Eggs & Young \\
\hline & $\begin{array}{l}\text { Old Wives Lake } \\
\text { (Sec. 28, 29, } 32 \& 33 \\
\text { T13, R29, W2) }\end{array}$ & June 17 & 2,600 & 1,420 & 2,498 & 4,773 \\
\hline 2) & $\begin{array}{l}\text { Quill Lakes } \\
\text { (Sec. } 27 \& 28, \\
\text { T34, R16, W2) }\end{array}$ & June 30 & & & & \\
\hline & - Colony a (island) & & & 20 & 30 & 41 \\
\hline & - Colony b (north shore) & & 459 & 118 & 67 & 300 \\
\hline 3) & $\begin{array}{l}\text { Primrose Lake } \\
\text { (Sec. 11, T69, R25, W3) }\end{array}$ & July 2 & & $\begin{array}{c}439 \\
(2,313)^{\star}\end{array}$ & 338 & 4,287 \\
\hline 4) & $\begin{array}{l}\text { Suggi Lake } \\
\text { (T62, R5 \& 6, W2) }\end{array}$ & July 6 & & & & \\
\hline & - Colony a (east island) & & 235 & 143 & & \\
\hline & - Colony b (west island) & & 300 & 182 & & 600 \\
\hline 5) & $\begin{array}{l}\text { Kazan Lake } \\
\text { (Sec. 13, T76, R16, W3) }\end{array}$ & July 7 & 550 & 275 & & \\
\hline 6) & $\begin{array}{l}\text { Redberry Lake** } \\
\text { (Sec. 1, T43, R9, W3) }\end{array}$ & June 29 & 70 & $\begin{array}{l}19 \\
(89)^{*}\end{array}$ & 3 & 175 \\
\hline 7) & Last Mt. Lake & June 10 & \multicolumn{4}{|c|}{ (no longer active) } \\
\hline 8) & Cumberland Lake & July 6 & \multicolumn{4}{|c|}{ (no longer active) } \\
\hline 9) & Doré Lake & July 7 & \multicolumn{4}{|c|}{ (no longer active) } \\
\hline \multirow[t]{2}{*}{ 10) } & Cypress Lake** & June 28 & \multicolumn{4}{|c|}{ (no longer active) } \\
\hline & & & 4,214 & 4,560 & 2,936 & $\overline{10,176}$ \\
\hline
\end{tabular}

${ }^{*}$ Combining the number of young and eggs and dividing by two which is the average number of eggs per nest, 1 arrived at this approximate number of nests. ${ }^{3}$

**Surveyed in 1977.

The pelican and cormorant colonies could only be reached by boat or airplane. If California or Herring Gulls were nesting near the pelicans or cormorants, counts were taken from a distance to reduce the risk of gull predation. On extremely hot, cold or stormy days, counts were not attempted in order to prevent mortality from exposure.

OBSERVATIONS. During the course of the survey, a total of 39 colonies was investigated; 10 White Pelican, 9 Double-crested Cormorant and 20 Great Blue Heron. Details are given in Tables 1 to 3. (a) White Pelican: Ten pelican areas were checked of which four no longer contained any evidence of nesting. These were Last Mountain Lake, Doré Lake, Cumberland Lake and Cypress Lake (Table 1). Lavallēe Lake was checked in 1975 by G. Trottier and R. Breneman. ${ }^{4}$ They counted 1,293 nests and indicated that this represented virtually no change over the last few years, so I felt it unnecessary to check the colony again in 1976.

Taking into consideration the estimated number of nests on Primrose Lake and Redberry Lake, I counted a total of 4,560 pelican nests (Table 1 ). In 


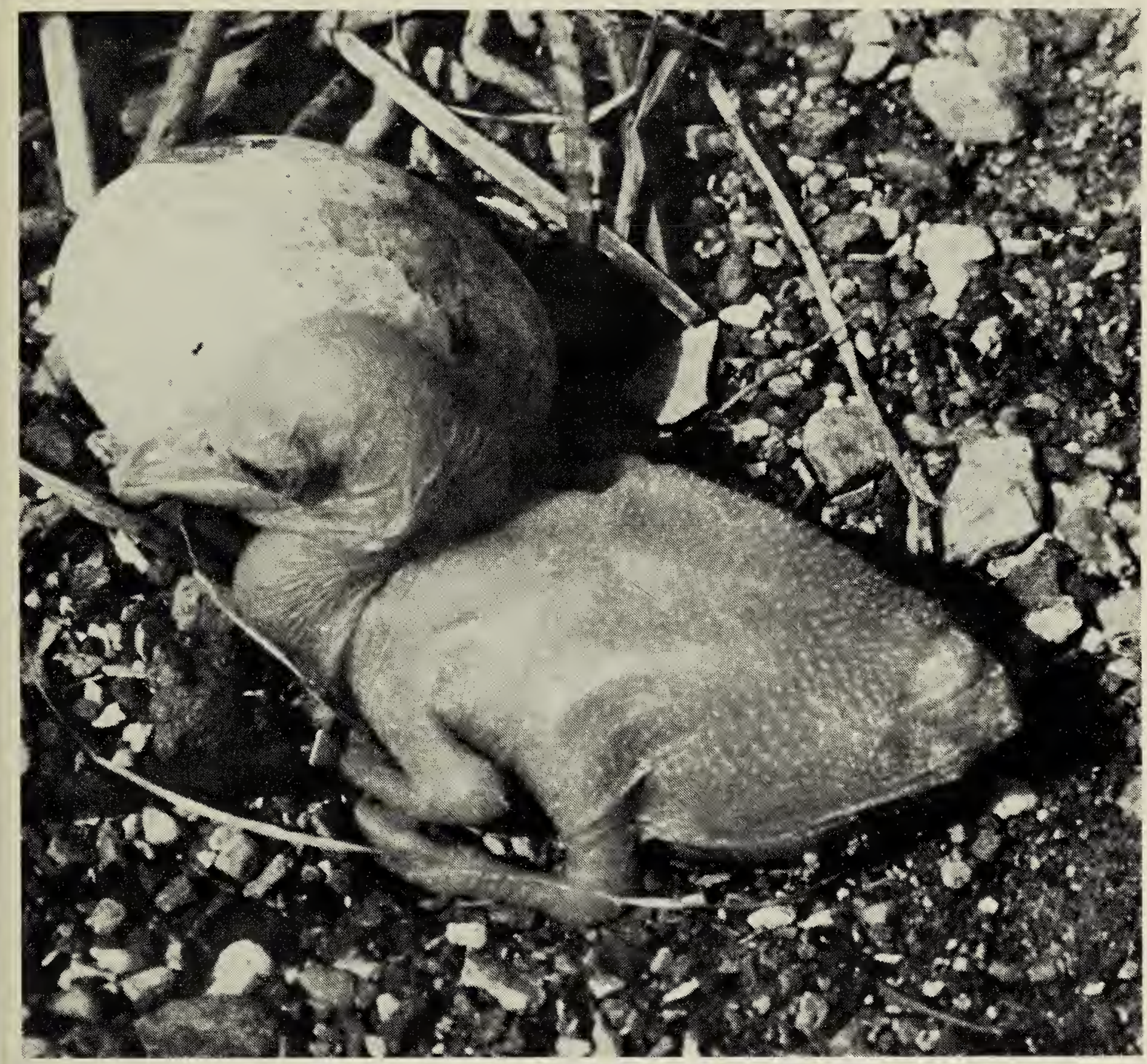

Young pelican and egg in nest

Keith Roney

1971 Boeker counted 2,865 nests while, for the same colonies, I counted 2,109 nests. Vermeer counted 5,538 nests in 1968 and for the same colonies I counted 4,422 nests. ${ }^{6}$ The overall breeding population of White Pelicans in Saskatchewan appears to be decreasing slightly. The significance of this decrease is difficult to assess because of the unknown bias introduced by different survey methods However, drastic changes have occurred within individual colonies.

On the positive side, the colony on Old Wives Lake has increased to almost double the 1968 figure. The pelicans have renested on the Quill Lakes after an absence of a few years. The colony at Lavallée Lake has remained stable while the Primrose
Lake colony appears to be decreasing slightly. Again, the Primrose figures may only be a reflection on the survey method. The colony on Redberry Lake seems to have stabilized since Boeker's survey in 1971.

Looking on the negative side, Doré Lake, Kazan Lake and Suggi Lake have decreased dramatically since 1968 There are no pelicans nesting-on Doré Lake in 1976 compared to Vermeer's 600 nests in 1968. Kazan Lake has decreased from 680 nests in 1968 to 275 nests in 1976, while Suggi Lake has decreased from 902 nests in 1968 to only 325 nests in 1976 . The colony on Cypress Lake has decreased from 12 nests in 1969 to none in 1977

As mentioned earlier, pelicans are 


\begin{tabular}{|c|c|c|c|c|c|}
\hline Location & $\begin{array}{l}\text { Date } \\
\text { Checked }\end{array}$ & Adults & Nests & Eggs & Young \\
\hline $\begin{array}{l}\text { 1) Cypress Lake } \\
\text { (Sec. 17, T6, R26, W3) }\end{array}$ & May 22 & 1,200 & $\begin{array}{l}320 \pm 10 \\
\text { active } \\
215 \pm 10 \\
\text { not active }\end{array}$ & $620 \pm 10$ & \\
\hline $\begin{array}{l}\text { 2) Last Mt. Lake* } \\
(\text { Sec. } 30, T 27, R 23, \text { W2) }\end{array}$ & June 11 & & $\begin{array}{l}117 \text { (5 not } \\
\text { active) }\end{array}$ & 122 & 186 \\
\hline $\begin{array}{l}\text { 3) Old Wives Lake } \\
\text { (Sec. 28, 29, 32,33, } \\
\text { T13, R29, W2) }\end{array}$ & June 17 & & 319 & 270 & 589 \\
\hline $\begin{array}{l}\text { 4) Quill Lakes } \\
\text { (Sec. 27 \& 28, } \\
\text { T34, R16, W2) }\end{array}$ & June 30 & & & & \\
\hline $\begin{array}{l}\text { - Colony a (island) } \\
\text { - Colony b (north shore) }\end{array}$ & & & $\begin{array}{r}32 \\
235\end{array}$ & 26 & $\begin{array}{r}69 \\
519\end{array}$ \\
\hline $\begin{array}{l}\text { 5) Primrose Lake } \\
(\text { Sec. 11, T69, R25, W3) }\end{array}$ & July 2 & & 43 & & 56 \\
\hline $\begin{array}{l}\text { 6) Suggi Lake } \\
\text { (T62, R5 \& } 6, W 2)\end{array}$ & July 6 & & & & \\
\hline - Colony a (east island) & & 190 & 73 & & \\
\hline - Colony b (west island) & & 300 & 147 & & \\
\hline $\begin{array}{l}\text { 7) Kazan Lake } \\
\text { (Sec. 13, T76, R16, W3) }\end{array}$ & July 7 & & 1,300 & & \\
\hline $\begin{array}{l}\text { 8) Doré Lake } \\
\text { (Sec. 7, T66, R10, W3) }\end{array}$ & July 7 & & 130 & & \\
\hline \multirow[t]{2}{*}{$\begin{array}{l}\text { 9) Redberry Lake** } \\
\text { (Sec. 1, T43, R9, W3) }\end{array}$} & June 29 & 32 & 29 & 16 & 40 \\
\hline & & $\overline{1,722}$ & $\overline{2,740}$ & $\overline{1,054}$ & $\overline{1,459}$ \\
\hline
\end{tabular}

*This colony was not active in 1977 (Clint Jorgenson, pers. comm.).

** Surveyed in 1977 .

no longer nesting on Cumberland or Last Mountain Lakes and appear to be in danger in other areas.

(b) Double-crested Cormorant: Nine traditional nesting areas for cormorants were surveyed. All nine colonies were active and a total count of 2,740 nests was made (Table 2). Comparing this with 954 nests recorded for the same colonies by Vermeer in 1968 , we see a marked overall increase. This was largely due to the Kazan Lake colony where the numbers rose from 152 nests in 1968 to 1,300 nests in 1976.

At Last Mountain Lake and the Quill Lakes cormorants have re-established themselves since the 1968 survey. Cypress Lake and Primrose Lake colonies seem to have decreased somewhat while the colonies at Doré, Old Wives and Suggi Lakes have had a substantial increase in numbers.

The number of cormorant nests recorded for Lavallée Lake shows an increased breeding success in Saskatchewan.

It should be mentioned that in 1977 no cormorants nested on Parry's Point, Last Mountain Lake (Sec. 30, T. 27, Rge. 23, W2) (C. Jorgenson, C.W.S., pers. comm.).

(c) Great Blue Heron: Since all the heron colonies were not checked, it is 
Table 3 - GREAT BLUE HERON COLONIES SURVEYED IN 1976

\begin{tabular}{|c|c|c|c|c|c|}
\hline Location & $\begin{array}{l}\text { Date } \\
\text { Checked }\end{array}$ & Adults & Nests & Eggs & Young \\
\hline $\begin{array}{l}\text { 1) Lumsden } \\
\text { (Sec. 26, T19, R22, W2) }\end{array}$ & & May 13 & \multicolumn{3}{|c|}{ (not active) -50 old nests } \\
\hline $\begin{array}{l}\text { 2) Craven } \\
\text { (Sec. 28, T20, R20, W2) }\end{array}$ & & May 13 & \multicolumn{3}{|c|}{ (not active) -10 old nests } \\
\hline $\begin{array}{l}\text { 3) Bone Creek } \\
\text { (Sec. } 4 \text { \& 9, T11, R20, W3) }\end{array}$ & & May 21 & \multicolumn{3}{|c|}{$\begin{array}{l}42 \pm \text { active } \\
\pm \text { not active }\end{array}$} \\
\hline $\begin{array}{l}\text { 4) Newton Lake } \\
(\text { Sec. } 28, T 4, R 14, W 3)^{*}\end{array}$ & & May 21 & \multicolumn{3}{|c|}{8 (7 active) } \\
\hline $\begin{array}{l}\text { 5) Harris Reservoir } \\
\text { (Sec. 8, T10, R26, W3) }\end{array}$ & & May 24 & \multicolumn{3}{|c|}{$75 \pm 5$ active $(70 \pm 5$ active } \\
\hline $\begin{array}{l}\text { 6) Tennaille Lake } \\
\text { (Sec. } 28, T 13, \text { R26, W3) }\end{array}$ & & May 24 & \multicolumn{3}{|c|}{6 (5 active) } \\
\hline $\begin{array}{l}\text { 7) Findlater } \\
\text { (Sec. } 2, T 22, R 26, W 2)\end{array}$ & & May 28 & \multicolumn{3}{|c|}{ (not active) -6 old nests } \\
\hline $\begin{array}{l}\text { 8) Girvin } \\
\text { (Sec. 14, T25, R28, W2) }\end{array}$ & & May 28 & \multicolumn{3}{|c|}{16 (11 active) } \\
\hline $\begin{array}{l}\text { 9) Moose Mt. Park } \\
\text { (Sec. 21, T10, R3, W2) }\end{array}$ & & June 2 & \multicolumn{3}{|c|}{ (not active) -1 old nest } \\
\hline $\begin{array}{l}\text { 10) Gillis Lake } \\
\text { (Sec. } 25, T 10, R 4, W 2)^{*}\end{array}$ & & June 3 & \multicolumn{3}{|c|}{10 (9 active) } \\
\hline $\begin{array}{l}\text { 11) Old Wives Lake } \\
\text { (Sec. 29, T13, R29, W2) }\end{array}$ & & June 17 & \multicolumn{3}{|l|}{64} \\
\hline $\begin{array}{l}\text { 12) Fir Mountain } \\
(\text { Sec. } 24, T 3, R 5, W 3)^{*}\end{array}$ & & June 18 & \multicolumn{3}{|l|}{15} \\
\hline $\begin{array}{l}\text { 13) Rockglen } \\
\text { (Sec. } 27, T 2, R 30, W 2)\end{array}$ & & June 18 & \multicolumn{3}{|l|}{31} \\
\hline $\begin{array}{l}\text { 14) Quill Lakes } \\
\text { (Sec. 10, T34, R16, W2)* }\end{array}$ & & June 30 & \multicolumn{3}{|l|}{19} \\
\hline $\begin{array}{l}\text { 15) Primrose Lake } \\
\text { (Sec. 11, T69, R25, W3) }\end{array}$ & & July 2 & \multicolumn{3}{|l|}{38} \\
\hline $\begin{array}{l}\text { 16) Ministikwan Lake } \\
\text { (Sec. 16\&17, T58, R25, W3) }\end{array}$ & & July 7 & \multicolumn{3}{|c|}{$45 \pm 5$} \\
\hline $\begin{array}{l}\text { 17) De Balinhard Lake } \\
\text { (Sec. 36, T63, R22, W3)* }\end{array}$ & & July 7 & \multicolumn{3}{|c|}{$35 \pm 5$} \\
\hline $\begin{array}{l}\text { 18) Kazan Lake } \\
\text { (Sec. } 13, T 76, R 16, W 3)\end{array}$ & & July 7 & \multicolumn{3}{|c|}{$30 \pm 5$} \\
\hline $\begin{array}{l}\text { 19) Bronson Lake } \\
\text { (Sec. } 29 \& 30, T 56, R 25, W 3)^{*}\end{array}$ & & July 8 & \multicolumn{3}{|c|}{$23 \pm 5$} \\
\hline $\begin{array}{l}\text { 20) St. Walburg } \\
\text { (Sec. } 18, T 56, R 22, W 3)^{*}\end{array}$ & & July 8 & \multicolumn{3}{|c|}{12} \\
\hline
\end{tabular}

* new colony

mpossible to assess their status.

In 1970, Vermeer checked 31 active

rechecked 13 of these colonies and found no drastic changes except at peronries in Saskatchewan. ${ }^{7}$ I Lumsden and Craven where the species 


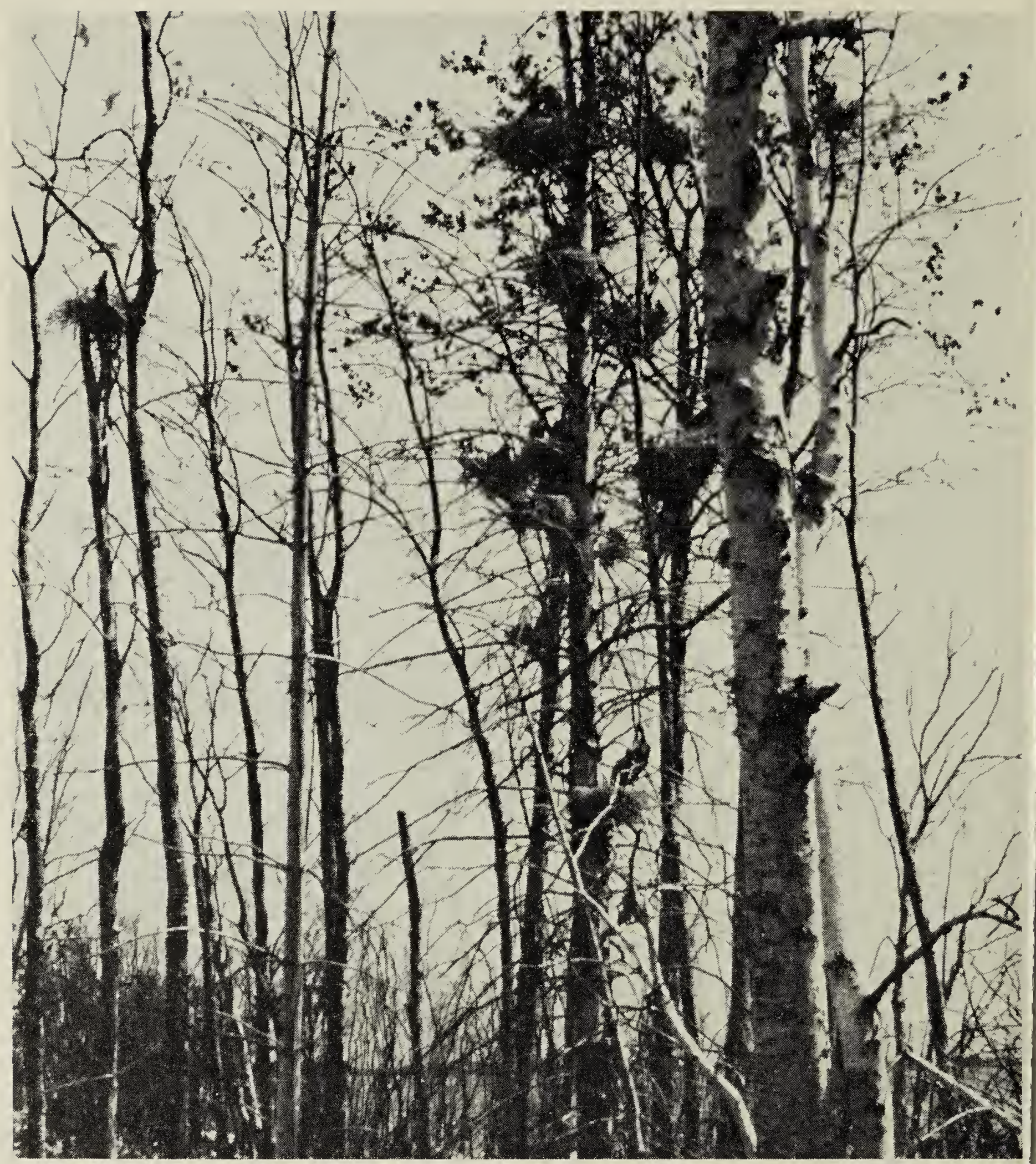

Cormorant nests in trees, Kazan Lake

Keith Roney

no longer breeds (Table 3 ). I recorded seven heronries not previously reported in the province.

Further surveys are required to complete the status on the Great Blue Heron.

RECOMMENDATIONS. Recommendations for the protection and further study of colonial nesters in Saskatchewan are listed below.

(a) Protection. 1) Existing legislation is inadequate. It must be strengthened and better enforced to offer complete protection within a $1 / 2$-mile radius of a colony; and an overhead flight minimum of 2,000 feet is essential. If this means shutting off the lake to all motorized or unmotorized (canoe, sailboat, etc.) craft, then this is what must be done. Human disturbance through recreational development and commercial fishing operations has been the direct cause of a reduction in breeding numbers on Doré, Suggi, Redberry and Cypress Lakes. 
2) To regulate all human activities on the colonies. This includes wildlife surveys, banding operations, biological studies, bird-watching, and so on. All must get prior written permission from the Department of Tourism and Renewable Resources before being allowed on a colony. Stiff penalties must be levied for anyone caught within the $1 / 2$-mile protective zone or minimum overhead flight restrictions without written authorization.

3) To adequately protect important foraging areas for breeding pelican and cormorant colonies, once these have been identified. The quality of foraging areas and the extent to which they are being used must also be assessed so that any environmental impact that would endanger the birds' success can be anticipated.

(b) Surveys. 1) White Pelican and Double-crested Cormorant colonies should be monitored every 2 years while Creat Blue Heron and other colonial nesters should be checked every 3 years.

These surveys would identify population declines in time to develop proper management techniques to combat such problems. Surveys should be by boat and motor and/or by aircraft. Data provided by G. Trottier suggests that aerial censusing is the most acceptable and least disturbing to the birds. ${ }^{4}$

2) A survey of all suitable water areas in the province, possibly as part of a general wetlands inventory, is required to locate additional colonies which undoubtedly exist.

(c) Public. An education program is required that stresses that people should stay away from bird colonies, especially during the breeding season. This is an extremely critical period and even the most innocent of visits to a colony at the wrong time could result in tremendous losses of eggs and young through predation or exposure to the elements. These disturbances may be the direct cause for nest desertion and eventual abandonment of the inactive sites noted above.
ACKNOWLEDCEMENTS. My thanks to the many individuals who reported useful observations of colonial nesters and to those who assisted in locating colonies while in the field.

The co-operation of the Hudson Bay Region of the Department of Tourism and Renewable Resources and, in particular, Dave Dalke for flying me on surveys of Cumberland and Suggi Lakes was appreciated.

I wish to thank Roger Cluckie and Paul Cochlin of the Alberta Fish and Wildlife Service for assisting on the survey of Primrose Lake.

A special thanks goes to Dr. Frank Scott of Loon Lake who so generously and freely gave of his home, time, and airplane to fly me on surveys of Loon Lake, Meadow Lake and Kazan Lake. Without his assistance, important field data would have gone unchecked.

'BENT, A. C. 1922. Life histories of North American petrels and pelicans and their allies. Smithsonian Inst. U.S. Nat. Mus. Bull. 121:282-293.

${ }^{2}$ BOEKER, E. L. 1972. A survey of White Pelican nesting colonies in 1971 American Birds 26:24; 125.

${ }^{3}$ SCHALLER, G. B. 1964. Breeding biology of the White Pelican at Yellowstone Lake, Wyoming. Condor 66:3-23.

${ }^{4}$ TROTTIER, G., and R. BRENEMAN. 1976. Population status and foraging distribution of White Pelicans breeding in Prince Albert National Park, Saskatchewan. Canadian Wildlife Service Report. unpubl.

${ }^{5}$ VERMEER, KEES. 1970a. Distribution and size of colonies of White Pelicans, Pelecanus erythrorhynchos, in Canada. Canadian J. Zool. 48:1029-1032

${ }^{6}$ VERMEER, KEES. 1970b. Colonies of Double-crested Cormorants and White Pelicans in Saskatchewan. Canadian Field-Nat. 84:39-42.

'VERMEER, KEES, and G. ANWEILER. 1970 Great Blue Heron coloniesin Saskatchewan in 1970. Blue Jay 28:158161. 